\title{
EFFECT OF MINERAL NITROGEN AND BIOFERTILIZER APPLICATION ON NODULATION EFFICIENCY AND GROWTH OF PEANUT PLANTS GROWN ON A SANDY SOIL TREATED WITH ORGANIC FERTILIZERS
}

\author{
E.A. Abou Hussien ${ }^{(1)}$, A. F. Abdel Wahab ${ }^{(2)}$, M. M. El-Shinnawi ${ }^{(1)}$, \\ M. F. Tantawy ${ }^{(2)}$ and N. E. A. El-Noamany ${ }^{(1)}$ \\ (1) Soil Sci. Dept., Fac. of Agric., Menoufia Univ., Shebin El-Kom, Egypt. \\ (2) Soils, Water and Environment Res. Inst., Agric. Res. Center, Giza, Egypt.
}

Received: Mar. 7, 2019

Accepted: Apr. 5, 2020

\begin{abstract}
A field experiment was carried out on a sandy soil of Experimental Farm, Ismailia Research Station, Soils, Water and Environment Research Institute, Agricultural Research Center (ARC), Egypt, during two successive growth summer seasons, i.e. 2016 and 2017 on peanut (Arachis hypogaea L.) Giza 5 cv., to study the individual and combined effect of applications of mineral $\mathrm{N}$ fertilization levels (25 and $40 \mathrm{~kg} \mathrm{~N} / \mathrm{fed}$., ammonium sulphate, $20.3 \% \mathrm{~N}$ ). Four resources of organic fertilizers (farmyard manure "FYM", solid plant compost "SPC", enriched compost tea "ECT" and FYM+ECT) and two different mixtures of biofertilizers $\left(B_{1}\right.$ and $\left.B_{2}\right)$ on nodulation efficiency and growth of peanut plants. $B_{1}$ consists of Azospirillum braselinse (local strain) + Bacillus megatherium (local strain) + Azotobacter chroococcum (local strain); while $B_{2}$ consists of Bradyrhizobium.sp ( strain (USDA 3456)) + Serratia marcescens ( strain MH6) + Psuedomonas fluorescens (strain IFO 2034). Application rate of SPC, FYM were 5 ton / fed., while ECT was $75 \mathrm{~L} / \mathrm{fed}$ (fed is $0.42 \mathrm{ha}$ ). The treatment of FYM+ECT was carried out at a rate of 2.5 ton FYM / fed. + 37.5 L ECT/ fed. The layout of the experiment was a splitsplit-plot design, with the main plots arranged in a randomized complete blocks design, with three replicates.
\end{abstract}

The results showed that, a marked significant increases in both nodules (number and dry matter) formed on the roots of peanut plants as well as the dry matter of shoots of peanut plants owing to the used fertilization treatments as compared to the control. The highest values of nodulation (number and weight) and shoots dry weights were found in the plants fertilized by triple combinations of mineral $N$, organic and biofertilizers followed by those found duo to the dual combinations. Data also showed a superior increase of applied $B_{2}$ and addition of ECT than that obtained for $B_{1}$ and either of than other organic fertilizers on nodules number as shoots dry weight of peanut plants at growth period of 45 days. Generally, data showed an importance role of mineral $\mathbf{N}$ and bio-fertilizers application on sandy soil fertility of sandy soil treated with organic fertilizers and its productivity of peanut plants.

Key words: Peanut, Sandy soil, Mineral nitrogen, Organic and Biofertilizers, Nodulation and Soil Fertility.

\section{INTRODUCTION}

Peanut or Groundnut (Arachis hypogaea $L$.) is best grown in semi-arid eco-systems where rainfall is low
(Hamidou et al., 2012) Sandy and sandy loam soils are of poor fertility and low water holding capacity (Latif et al., 2014); low soil organic matter (Samuel, 2013) and thus poor fertilizer use efficiency. 
The nutrient and water holding capacity of such soils can be improved through adding organic materials (Latif et al., 2014). Thus combined use of mineral and organic fertilizers like manures, compost and vermicompost (VC) is becoming increasingly important (Chouichom and Yamao, 2011). Peanut is considered the main oil crop grown in Egypt. It is an important oil duo to its high nutritive value. It contains about $50 \%$ oil, $25-30 \%$ protein, $20 \%$ carbohydrate and $5 \%$ fiber and ash, which make a substantial contribution to human nutrition (Fageria et al., 1997). Peanut offers ecosystem services such as renewable inputs of nitrogen into crops and soil via biological ambient $\mathrm{N}_{2}$ fixation. Increasing peanut productivity largely depends on improving the cultural practices such as soil fertility by utilization of organic fertilization, which may help to solve soil problem (Siam et al., 2015).

Sandy soils cover vast areas in Egypt. Therefore, reclamation of these soils is the main target for the horizontal expansion of our cultivable land. Unfortunately, sandy soils have very poor hydrophysical and nutritional values. Thus, the use of soil amendments is of vital importance to improve physical, chemical and nutritional characteristics of these soils. So, fertilization with different elements and also application of gypsum as a source of $\mathrm{Ca}$ and $\mathrm{S}$ elements to these soils enhance the vegetative growth of crops where, $\mathrm{Ca}$ and $\mathrm{S}$ nutrients are often a yield limiting factor for peanut and are necessary for pod growth and increasing peg strength.

Nitrogen $(\mathrm{N})$ is an element required for plant growth where it is an important component of proteins, enzymes and vitamins in plant. It is a central part of the chlorophyll and essential photosynthetic molecule. The excessive application of mineral fertilizers increases production cost. The residual of mineral fertilizers seriously and ngatively affect the quality of agricultural products, people's health and causs environmental pollution. Therefore a great interest has been generated to apply bioorganic and inorganic fertilizers to establish a good ecoenvironment for plant growth (Basak, 2006). Nitrogen fertilizers are economically an expensive input. In many instances less than $60 \%$ of the added $\mathbf{N}$ is recovered by the crop and soil with the remainder being lost by processes such as volatilization, leaching, immobilization and denitrification. Thus, it is necessary to develop fertilizer management practices that can reduce losses and increase the nitrogen use efficiency (Yusron and Phillips, 1997).

Organic fertilization deficiency limits the production of many crops especially grain legumes in many soils. Nowadays there is a high demand on the organic products. Organic agriculture (application of organic matter soil and no use of mineral compounds) is a production management system that aims to promote and enhance ecosystem health, including biological cycles and soil biological activity and minimize the use of external inputs (Rasul and Thapa, 2003 and Ghaly et al., 2018).

The use of biofertilizers is important for sustainable agriculture, and the use of nodule bacteria and endophytic actinomycetes is an attractive way to enhance plant growth and yield. Biofertilizers are alternatives of mineral fertilizers to increase soil productivity and plant growth in a sustainable agriculture regime. (EI-Noamany, 2013 and Htwe et al., 2019). The legumeRhizobium symbiotic relationship is a very important practice, particularly under the intensive cropping system, in order to decrease the chemical inputs and to raise soil quality and 
sustainability. Rhizobium-legume symbiosis is thus considered as the most efficient and necessary process in crop production. Leguminous plants in a partnership with members of the bacterial genera Rhizobium and Bradyrhizobium have the ability to convert the atmospheric nitrogen into usable forms. The inoculation with either micro - symbiont meets $50-70 \%$ of the crop nitrogen requirement and increases legumes productivity (Amarger, 2001 ; Ndakidemi et al., 2006 and Tena et al., 2016).

The aim of the present study is to develop a suitable fertilization management system, that use three types of fertilization (mineral nitrogen, bio and organic fertilizers), as integrated regime of fertilization "IRF", for peanut plants (Arochis hypogaea L.) "variety Giza 5" cultivated in a sandy soil. Also, This study aimes at investigating the effect of the studied treatments on nodulation (number and dry weight) and growth of peanut plants. Finally, the rationalization use of mineral - N fertilization is one of the important aims of this study.

\section{MATERIALS AND METHODS}

A field experiment was carried out on a sandy soil of the Experimental Farm, Ismailia Research Station, Soils, Water and Environment Research Institute , Agricultural Research Center (ARC), Egypt, during two successive growth summer seasons, i.e. 2016 and 2017 on peanut (Arachis hypogaea L.) Giza 5 cv., to study the individual and combined effect of applications of mineral $\mathrm{N}$ fertilizer levels\{ $(25$ and $40 \mathrm{~kg} \mathrm{~N} /$ fed., ammonium sulphate, $20.3 \% \mathrm{~N})=(\mathrm{N} 1$ and N2) \}, four resources of organic fertilizers (farmyard manure "FYM" , solid plant compost "SPC", enriched compost tea "ECT" and FYM +ECT), plus control $\left(\mathrm{O}_{0}\right)$ and two different mixtures of biofertilizer
( $B_{1}$ and $\left.B_{2}\right)$, plus control $\left(B_{0}\right)$ on nodulation efficiency and growth of peanut plants. $B_{1}$ consists of Azospirillum braselinse (local strain) + Bacillus megatherium ( local strain) + Azotobacter chroococcum( local strain); while $B_{2}$ consists of Bradyrhizobium.sp ( strain (USDA 3456) ) + Serratia marcescens (strain MH6) + Psuedomonas fluorescens (strain IFO 2034). Application rate of SPC, FYM were 5 ton / fed., while that of ECT was $75 \mathrm{~L} / \mathrm{fed}$. The treatment FYM +ECT was carried out at a rate of 2.5 ton FYM / fed. + 37.5 L ECT/ fed. All agricultural practices beginning from preparation of soil to planting until harvesting were carried out as recommended by Egyptian Ministry of Agriculture.

Before planting, surface soil samples $(0-20 \mathrm{~cm})$ were taken from the experimental soil, air-dried, ground, mixed throughtly, sieved through a $2 \mathrm{~mm}$ sieve, kept and there after were analyzed for some physical as well as chemical properties and its content (total and available) of $\mathrm{N}, \mathrm{P}$ and $\mathrm{K}$ according to the methods described by Cottenie et al. (1982) ; Page et al. (1982) and Kim (1996). The obtained data were recorded in Table (1).

\section{Sources of the organic fertilizers}

The used organic fertilizers were :-

1- Enriched compost tea "ECT", prepared from a well mature compost and enriched with humic. ECT preparation and purification processes were carried out according to the methods described by AbdelWahab et al. (2007).

2- Solid plant compost "SPC" prepared from plant residues at Agricultural Microbiology Research Department, Soils, Water and Environment Research Institute 
Table (1): Some physical and chemical properties and some nutrients content of the studied soil.

\begin{tabular}{|c|c|c|c|c|c|c|c|c|c|c|c|c|}
\hline \multicolumn{13}{|c|}{ a. Physical properties } \\
\hline \multicolumn{13}{|c|}{ Particles size distribution (\%) } \\
\hline \multicolumn{2}{|c|}{ Sand } & \multicolumn{3}{|c|}{ Silt } & \multicolumn{3}{|c|}{ Clay } & \multicolumn{5}{|c|}{ Textural class } \\
\hline \multicolumn{2}{|c|}{90.6} & \multicolumn{3}{|c|}{4.6} & \multicolumn{3}{|c|}{4.8} & \multicolumn{5}{|c|}{ Sandy } \\
\hline \multicolumn{13}{|c|}{ b. Chemical properties } \\
\hline \multirow{3}{*}{$\begin{array}{l}\text { Organic } \\
\text { matter } \\
\mathrm{g} \mathrm{kg}^{-1}\end{array}$} & \multirow{3}{*}{$\begin{array}{l}\mathrm{CaCO}_{3} \\
\mathrm{~g} \mathrm{~kg}^{-1}\end{array}$} & \multirow{3}{*}{$\begin{array}{c}\mathrm{pH} \\
(1: 2.5) \\
\text { soil:water } \\
\text { suspension }\end{array}$} & \multirow{3}{*}{\multicolumn{2}{|c|}{$\begin{array}{l}\mathrm{EC}\left(\mathrm{dSm}^{-1}\right) \\
\text { Saturated } \\
\text { Soil paste }\end{array}$}} & \multicolumn{8}{|c|}{ 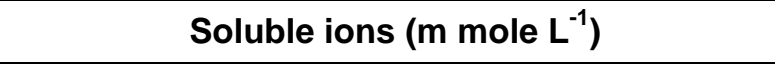 } \\
\hline & & & & & \multicolumn{4}{|c|}{ Cation } & \multicolumn{4}{|c|}{ Anion } \\
\hline & & & & & $\mathrm{Ca}^{2+}$ & $\mathbf{M g}^{2+}$ & $\mathrm{K}^{+}$ & $\mathrm{Na}^{+}$ & $\mathrm{CO}_{3}{ }^{2-}$ & $\mathrm{HCO}_{3}$ & $\mathrm{Cl}^{-}$ & $\mathrm{SO}_{4}{ }^{2-}$ \\
\hline 4.0 & 16 & 7.6 & & .31 & 0.7 & 0.6 & 0.3 & 1.5 & 0.0 & 1.6 & 0.7 & 0.8 \\
\hline \multicolumn{13}{|c|}{ c. Nutrient contents $\left(\mathrm{mg} \mathrm{kg}^{-1}\right)$} \\
\hline \multicolumn{4}{|c|}{$\mathbf{N}$} & \multicolumn{4}{|c|}{$\mathbf{P}$} & \multicolumn{5}{|c|}{$\mathbf{K}$} \\
\hline \multicolumn{2}{|c|}{ Total } & \multicolumn{2}{|c|}{$\begin{array}{l}\text { Available was } \\
\text { extracted with } 1 \mathrm{~N} \\
\text { KCL }\end{array}$} & Total & \multicolumn{3}{|c|}{$\begin{array}{c}\text { Availablewas } \\
\text { extracted } \\
\text { with0.5N } \\
\mathrm{NaHCO}_{3}\end{array}$} & \multicolumn{3}{|c|}{ Total } & \multicolumn{2}{|c|}{$\begin{array}{c}\text { Availablewas } \\
\text { extracted } \\
\text { with } 1 \mathrm{~N} \\
\text { ammonium } \\
\text { acetate }\end{array}$} \\
\hline \multicolumn{2}{|c|}{221.0} & \multicolumn{2}{|l|}{31.00} & 62.30 & \multicolumn{3}{|c|}{5.3} & \multicolumn{3}{|c|}{489.60} & \multicolumn{2}{|c|}{57.50} \\
\hline
\end{tabular}

Research, Agricultural Research Center (ARC), Egypt. Compost used was prepared from rice straw and farmyard manure provided with bentonite, rock phosphate, elemental sulphur and urea, which were composted for three months, according to the methods described by Abdel-Wahab et al. (2008) were added.

3- Farmyard manure "FYM" which was taken from Private Animal Farm Breading.

4- Mixture of farmyard manure and enriched compost tea "FYM" + "ECT".

All samples of organic fertilizers were analyzed for their chemical composition according to the methods described by Cottenie et al. (1982). The obtained data are recorded in Table (2).

\section{Preparation of biofertilizers}

Bio-fertilizers preparation was done by using two different mixtures $\left(B_{1}\right.$ and $B_{2}$ ) (blends) of bacterial agents supplied by Agricultural Microbiology Research Department, Soils, Water and Environment Research Institute, Agricultural Research Center (ARC), Egypt. All the bacterial agents were used as plant growth promoting rhizobacteria (PGPR) and are represented by the following mixtures:-

- $\mathrm{B}_{1}$ consists of Azospirillum braselinse (local strain) + Bacillus megatherium (local strain) + Azotobacter chroococcum ( local strain).

- $\mathrm{B}_{2}$ consists of Bradyrhizobium.sp (strain (USDA 3456)) + Serratia marcescens (strain MH6) + Psuedomonas fluorescens (strain IFO 2034). 
Table (2): Some chemical properties of the used three organic fertilizers.

\begin{tabular}{|c|c|c|c|c|c|c|c|c|}
\hline \multirow{3}{*}{$\begin{array}{l}\text { Sources of } \\
\text { organic } \\
\text { fertilizers } \\
\text { (OF) }\end{array}$} & Organic & Organic & Total & \multirow{3}{*}{$\begin{array}{l}\mathrm{C} / \mathrm{N} \\
\text { ratio }\end{array}$} & \multirow{3}{*}{$\begin{array}{c}\text { pH } \\
(1: 10) \text { OF: } \\
\text { water } \\
\text { suspension }\end{array}$} & \multirow{3}{*}{ 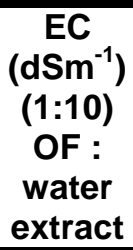 } & \multicolumn{2}{|c|}{ Total } \\
\hline & C & matter & $\mathbf{N}$ & & & & $\mathbf{P}$ & $\mathrm{K}$ \\
\hline & \multicolumn{3}{|c|}{ (\%) } & & & & \multicolumn{2}{|c|}{ (\%) } \\
\hline $\begin{array}{c}\text { Enriched } \\
\text { compost } \\
\text { tea "ECT" }\end{array}$ & 5.80 & 9.99 & 0.41 & 14.15 & 6.85 & 3.89 & 0.57 & 0.82 \\
\hline $\begin{array}{c}\text { Solid plant } \\
\text { compost } \\
\text { "SPC" }\end{array}$ & 18.00 & 31.03 & 1.42 & 12.68 & 7.79 & 3.53 & 0.46 & 1.60 \\
\hline $\begin{array}{c}\text { Farmyard } \\
\text { manure } \\
\text { "FYM" }\end{array}$ & 22.05 & 38.01 & 1.20 & 18.37 & 8.38 & 3.80 & 0.70 & 1.90 \\
\hline
\end{tabular}

The layout of the experiment was a split-split-plot design, with the main plots arranged in a randomized complete blocks design, with three replicates. The experimental plots were 90 units including 2 levels of mineral $N$ fertilization $\times$ four resources of organic fertilizers, plus control $\times$ two different mixtures of biofertilizer, plus control $x$ three replicates. The area of each plot was $21 \mathrm{~m}^{2}$ (7 m length $\times 3 \mathrm{~m}$ width), including 5 rows. The experimental plots were divided into two main groups (45 plots / main group), each of which was treated with either of the mineral $\mathbf{N}$ fertilization levels (25 or $40 \mathrm{~kg} \mathrm{~N} /$ fed., ammonium sulphate, $20.3 \% \mathrm{~N}$ ). It was added in two equal doses, after 20 and 30 days of planting. The sub main plots were represented by the biofertilizer, where peanut seeds were inoculated with gamma irradiated vermiculite based inoculums at a rate of $300 \mathrm{~g} / 50 \mathrm{~kg}$ seeds using $16 \%$ Arabic gum solution as a sticking agent. Moreover, the sub-sub main plots were treated with either of the used organic fertilizers (ECT, SPC, FYM or FYM+ECT). Before planting, SPC and FYM were added at a rate of 5 ton/fed, while, ECT was added at a rate of $75 \mathrm{~L} /$ fed., after 20 and 30 days of planting. The treatment of FYM+ECT was carried out at a rate of 2.5 ton FYM / fed. $+37.5 \mathrm{~L}$ ECT/ fed. Also, before planting, during the final soil preparation, all plots were fertilized by ordinary super phosphate $\left(15.5 \% \mathrm{P}_{2} \mathrm{O}_{5}\right)$ at a rate of $200 \mathrm{~kg} \mathrm{/} \mathrm{fed.}$ beside of agricultural gypsum at a rate of $500 \mathrm{~kg} / \mathrm{fed}$. At the same time of mineral $\mathrm{N}$ fertilization, all plots received potassium fertilizer in the form of potassium sulphate $\left(48 \% \mathrm{~K}_{2} \mathrm{O}\right)$ at rate of $100 \mathrm{~kg} / \mathrm{fed}$., in both two seasons.

Directly after inoculation, peanut (Giza 5 cv.; kindly provided from Field Crop Research Institute, Agriculture Research Center, Giza, Egypt) seeds were planted on $10^{\text {th }}$ and $15^{\text {th }}$ of May 2016 and 2017 in the two seasons, respectively at a seeding rate of $50 \mathrm{~kg}$ seeds / fed., thus 2 seeds for each hole at $2 \mathrm{~cm}$ depth at distance of $20 \mathrm{~cm}$ between holes. After 15 days of planting, the plants of each hole were thinned to one plant.

In both the two seasons, after $\mathbf{4 5}$ days of planting, the plants of one length meter of each replicate were taken separately counted and separated into roots and shoots. Shoots of the plants of each sample were air-dried, oven-dried at $70{ }^{\circ} \mathrm{C}$ for $48 \mathrm{~h}$, to determine the following parameters: - 
1- Number of nodules/plant (formed on the roots of peanut plant).

2- Weight of nodules roots ( $\mathrm{g} / \mathrm{plant}$ ).

3- Weight of dry matter shoots (g/plants $/ \mathrm{m})$.

4- Finally, the relative change ( $\%$ ) of the obtained data were calculated,

where: the relative change $(\%)=$

\{ (Parameter value duo to the treatment Parameter value in the control) I Parameter value in control $\} \times 100$.

All the data obtained from this study were analyzed using analysis of variance as described by Snedecor and Cochran (1980). The statistical analysis was done using costat package program, version 6.4 (Cohort software, USA). The differences among the means of different treatments were tested using the least significant differences (L.S.D.) at probability level of $5 \%$.

\section{RESULTS AND DISCUSSION}

Effect of mineral $\mathbf{N}$ fertilization levels, biofertilizer and organic fertilizers on:

\section{1- Nodules number:}

The data presented in Tables $(3,4$ and 5) show that, the number of nodules formed on the roots of peanut plants grown on the sandy soil after $\mathbf{4 5}$ days of planting and their relative changes duo to the different treatments under study. The of nodules number increased from 23.00 nodules/plant duo to the treatment $\mathrm{N} 1+$ $\mathrm{B}_{0}+\mathrm{O}_{0}$ to 27.67 nodules/plant duo to the treatment $\mathrm{N} 2+\mathrm{B}_{0}+\mathrm{O}_{0}$, thus relative change ( $\%$ ) owing to the mineral $\mathbf{N}$ fertilization levels (RCM) was $20.30 \%$. This result also show the important effect of the added rate of mineral $\mathrm{N}$ on nodules number under sandy soil conditions. In this respect, Gad (2006) ; Bekele et al. (2019) and Tantawy et al. (2019) obtained similar results with pea ; groundnut and common bean plants, respectively.
All observation emphasize the beneficial effect of biofertilizers ( $B_{1}$ and $B_{2}$ ) on nodules number. where Tables ( 3 and 4) reveal that inoculation with biofertilizers resulted in a significant increases in the nodules number formed on the roots of peanut grown under the sandy soil conditions. This positive effect was found duo to individual applications of the biofertilizers as well as duo to their combined treatments with mineral $\mathrm{N}$ and organic fertilizers. Duo to the individual application of $\mathrm{B}_{1}+\mathrm{N} 1+\mathrm{O}_{0}$, the relative change $(\%)$ owing to biofertilization (RCB) was value $13.04 \%$ (Table,4), where the nodules number increased from 23.00 to 26.00 nodule/plant duo to the treatments $\mathrm{N} 1+\mathrm{B}_{0}+\mathrm{O}_{0}$ and $\mathrm{N} 1+\mathrm{B}_{1}+\mathrm{O}_{0}$, respectively. Under the same treatment of mineral $\mathrm{N}$ and/or organic fertilizers, nodules number formed on the roots of peanut plants biofertilized by $B_{2}$ were higher than the corresponding ones formed on the rate of the plants fertilized by $B_{1}$. For example, nodules number resulted from the treatment $\mathrm{N} 1+\mathrm{B}_{1}+\mathrm{O}_{0}$ was $26.00 \mathrm{no} / \mathrm{plant}$ increased to 32.00 no/plant with the treatment $\mathrm{N} 1+\mathrm{B}_{2}+\mathrm{O}_{0}$ by RCB value of 13.04 and $39.13 \%$ compared to the corresponding ones resulted duo to the treatment $\mathrm{N} 1+\mathrm{B}_{0}+\mathrm{O}_{0}$. These findings show the high efficiency of nodulation process as a result of biofertilization especially with the treatment $B_{2}$. Abbas et al. (2011); ElNoamany (2013) and Mbah and Dakora (2018) found augments positive effect of biofertilization on nodules formation on soybean ; faba bean and some legumes plants (soybean ; Bambara groundnut ; and Kersting's groundnut), respectively.

More of nodules formed on the roots of peanut plants were found in the plants grown on the soil treated with combined application of the mineral $\mathrm{N}$ and biofertilizers $\left(B_{1}\right.$ and $\left.B_{2}\right)$ as compared with those found duo to either of the individual applications (Table, 3). So, RCB (\%) of nodules number duo to these 


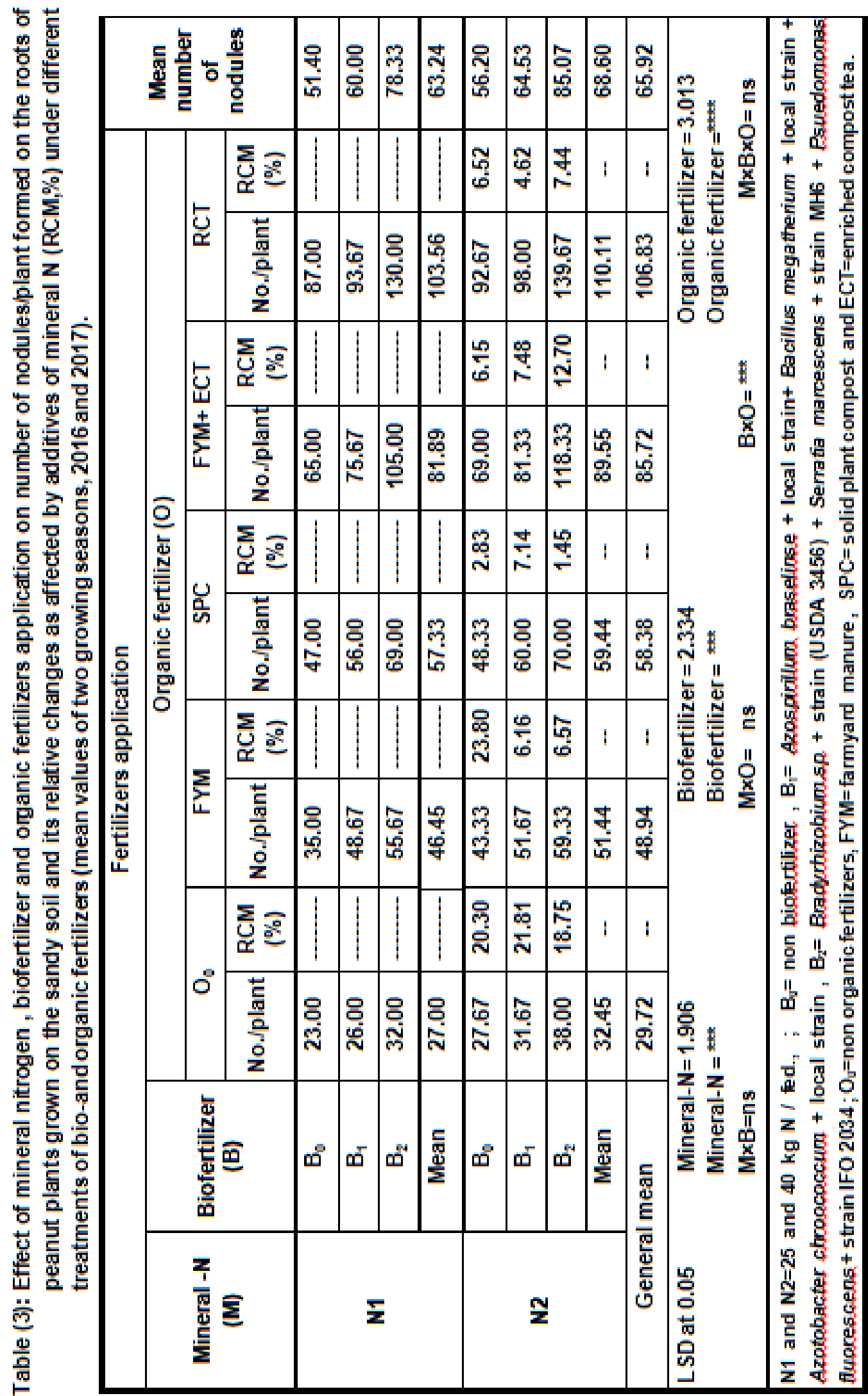


Table (4): Relative changes of nodules number /plant formed on the roots of peanut plants grown on the sandy soil as affected by bio-fertilizer applications (RCB , $\%$ ) under different treatments of mineral and organic fertilizers (mean values of two growing seasons, 2016 and 2017).

\begin{tabular}{|c|c|c|c|c|c|c|}
\hline \multicolumn{7}{|c|}{ Fertilizers application } \\
\hline \multirow{2}{*}{$\begin{array}{c}\text { Mineral }-\mathrm{N} \\
(\mathrm{M})\end{array}$} & \multirow{2}{*}{$\begin{array}{c}\text { Biofertilizer } \\
\text { (B) }\end{array}$} & \multicolumn{5}{|c|}{ Organic fertilizer $(0)$} \\
\hline & & $\mathrm{O}_{0}$ & FYM & SPC & $F Y M+E C T$ & ECT \\
\hline \multirow{3}{*}{ N1 } & $\mathrm{B}_{0}$ & -- & -- & -- & -- & -- \\
\hline & $\mathrm{B}_{1}$ & 13.04 & 48.57 & 19.15 & 16.41 & 7.67 \\
\hline & $\mathrm{B}_{2}$ & 39.13 & 59.06 & 46.81 & 61.54 & 49.42 \\
\hline \multirow{3}{*}{ N2 } & $B_{0}$ & - & - & - & - & - \\
\hline & $B_{1}$ & 14.46 & 19.25 & 24.14 & 17.87 & 5.75 \\
\hline & $\mathrm{B}_{2}$ & 37.33 & 36.92 & 37.95 & 71.50 & 50.72 \\
\hline \multicolumn{7}{|c|}{$\begin{array}{l}\mathrm{N} 1 \text { and } \mathrm{N} 2=25 \text { and } 40 \mathrm{~kg} \mathrm{~N} / \text { fed., ; } \mathrm{B}_{0}=\text { non biofertilizer, } \mathrm{B}_{1}=\text { Azospirillum braselinse }+ \text { local } \\
\text { strain }+ \text { Bacillus megatherium }+ \text { local strain }+ \text { Azotobacter chroococcum }+ \text { local strain }, \mathrm{B}_{2}= \\
\text { Bradyrhizobium.sp + strain (USDA } 3456)+ \text { Serratia marcescens }+ \text { strain MH } 6+\text { Psuedomonas } \\
\text { fluorescens }+ \text { strain IFO } 2034 ; \mathrm{O}_{0}=\text { non organic fertilizers, } \mathrm{FYM}=\text { farmyard manure , SPC }=\text { solid } \\
\text { plant compost and ECT=enriched compost tea. }\end{array}$} \\
\hline
\end{tabular}

Table (5): Relative changes of nodules number/plant formed on the roots of peanut plants grown on the sandy soil as affected by organic fertilizer applications, (RCO\%) under different treatments of mineral and biofertilizers (mean values of two growing seasons, 2016 and 2017).

\begin{tabular}{|c|c|c|c|c|c|}
\hline \multicolumn{6}{|c|}{ Fertilizers application } \\
\hline \multirow{2}{*}{$\begin{array}{c}\text { Mineral-N } \\
\text { (M) }\end{array}$} & \multirow{2}{*}{$\begin{array}{l}\text { Biofertilizer } \\
\text { (B) }\end{array}$} & \multicolumn{4}{|c|}{ Organic fertilizer $(0)$} \\
\hline & & FYM & SPC & FYM+ ECT & ECT \\
\hline \multirow{3}{*}{ N1 } & $\mathrm{B}_{0}$ & 52.17 & 104.35 & 182.61 & 278.26 \\
\hline & $B_{1}$ & 87.19 & 115.38 & 191.04 & 260.27 \\
\hline & $\mathrm{B}_{2}$ & 73.97 & 115.62 & 228.12 & 306.25 \\
\hline \multirow{3}{*}{ N2 } & $\mathbf{B}_{0}$ & 56.59 & 74.66 & 149.37 & 234.91 \\
\hline & $B_{1}$ & 63.15 & 89.45 & 156.80 & 209.44 \\
\hline & $\mathbf{B}_{2}$ & 56.13 & 84.21 & 211.39 & 267.55 \\
\hline \multicolumn{6}{|c|}{$\begin{array}{l}\mathrm{N} 1 \text { and } \mathrm{N} 2=25 \text { and } 40 \mathrm{~kg} \mathrm{~N} / \text { fed., } ; \mathrm{B}_{0}=\text { non biofertilizer, } \mathrm{B}_{1}=\text { Azospirillum braselinse }+ \text { local } \\
\text { strain }+ \text { Bacillus megatherium + local strain }+ \text { Azotobacter chroococcum }+ \text { local strain }, \mathrm{B}_{2}= \\
\text { Bradyrhizobium.sp + strain (USDA } 3456)+ \text { Serratia marcescens }+ \text { strain MH }+ \text { Psuedomonas } \\
\text { fluorescens + strain IFO } 2034 ; \mathrm{O}_{0}=\text { non organic fertilizers, FYM= farmyard manure , SPC= solid } \\
\text { plant compost and ECT=enriched compost tea. }\end{array}$} \\
\hline
\end{tabular}


combined applications were higher than those formed duo to their individual application (Tables, 3 and 5). This findings show the high importance of both mineral $\mathrm{N}$ and biofertilization on nodules formation. Dikand et al. (2012) showed that nodulation and nitrogen fixation in $\mathrm{N}$-fertilized soybean were low compared to any bradyrhizobium inoculations.

The nodules number formed on the roots of peanut plants planted in the sandy soil treated with the organic fertilizers whereas applied individually or in combination with mineral $\mathbf{N}$ and/or bio fertilizers resulted in a wide variations depending mainly on the added organic fertilizers (Tables, 3 and 5). All applications of organic fertilizers resulted in an increases of nodules number per plant of peanut. According to the formed nodules number, the efficiency of the tested organic fertilizers may be arranged in the following order: $\mathrm{ECT}>\mathrm{FYM}+\mathrm{ECT}>\mathrm{SPC}>\mathrm{FYM}>\mathrm{O}_{0}$ (control treatment). For example, with the treatment $\mathrm{N} 1+\mathrm{B}_{0}+\mathrm{O}_{0}$, the number of nodules increased from 23.00 to $35.00,47.00,65.00$ and $87.00 \mathrm{no} /$ plant with relative changes, of organic fertilizers (RCO) of $52.17 \%, 104.35 \%$, $182.61 \%, 278.26 \%$ duo to application of FYM, SPC, FYM+ECT, and ECT as compared to the treatment of $\mathrm{O}_{0}$, respectively. Similar trends were attained with all combined applications of organic fertilizers with both mineral $\mathbf{N}$ and biofertilization. This trend was in harmony with the chemical compositions of these manures especially their $\mathrm{C} / \mathrm{N}$ ratios and their contents of the essential plant nutrients as well as to their effects on improving soil physical and chemical properties. Abbas et al. (2011) found that farmyard manure (FYM) treatment has increased nodulation root (numbers and dry weight).

More significant increases of nodules number formed on the roots of peanut plants grown in sandy soil were found in the plants treated by dual applications of mineral $-\mathbf{N}+$ organic fertilizers (Tables, 3, 4 and 5). The values of RCM, RCB and RCO reveal such an effect. Vessey and Buss (2002) and Sulfab et al. (2011), showed that organic manure either alone or with Rhizobium inoculation plus $20 \mathrm{~kg} \mathrm{~N}^{-1}$ significantly increased groundnuts nodulation. The triple applications of mineral $N$, biofertilizers $\left(B_{1}\right.$ or $\left.B_{2}\right)$ and either of FYM, SPC, FYM+ECT or ECT were of more pronounced effects on nodulation probably duo to improving fertility as a result of these applications. The highest nodules number was found in the plants grown in the sandy soil treated with triple application of $\mathrm{N} 2+\mathrm{B}_{2}+\mathrm{ECT}$ followed by the treatment $\mathrm{N} 2+\mathrm{B}_{2}+\mathrm{FYM}$ with ECT while the lowest effect of the triple combinations was recorded with the treatment $\mathrm{N} 1+\mathrm{B}_{1}+\mathrm{FYM}$.

\section{2- Nodules weight:}

The data presented in Tables $(6,7$ and 8$)$ showed nodules weight $(\mathrm{g} / \mathrm{plants} / \mathrm{m})$ formed on the roots of peanut grown in sandy soil and their relative changes as affected by both individual and combined applications mineral $N$, biofertilizers $\left(B_{1}\right.$ and $\left.B_{2}\right)$ and organic fertilizers (FYM, SPC, ECT and FYM + ECT. All these applications resulted in significant increases in nodules weight as $\mathrm{g} / \mathrm{plants} / \mathrm{m}$. So all RCM, RCB and RCO (\%) were positive. The lowest value of nodules weight $(0.20 \mathrm{~g} / \mathrm{plants} / \mathrm{m})$ was found on the roots of peanut plants treated by $\mathrm{N} 1+\mathrm{B}_{0}+\mathrm{O}_{0}$, whereas the highest $(0.74 \mathrm{~g} / \mathrm{plants} / \mathrm{m})$ one was found in the plants grown in the sandy soil fertilized by $\mathrm{N} 2+\mathrm{B}_{2}+\mathrm{ECT}$.

Increasing rate of the added mineral $\mathrm{N}$ to the sandy soil from $25 \mathrm{~kg} / \mathrm{fed}$. (N1) to 40 $\mathrm{kg} / \mathrm{fed}$. (N2) resulted in significant increases in nodules weight from $0.20 \mathrm{~g} / \mathrm{plants} / \mathrm{m}$, with the treatment of 
E.A. Abou Hussien, et al.,

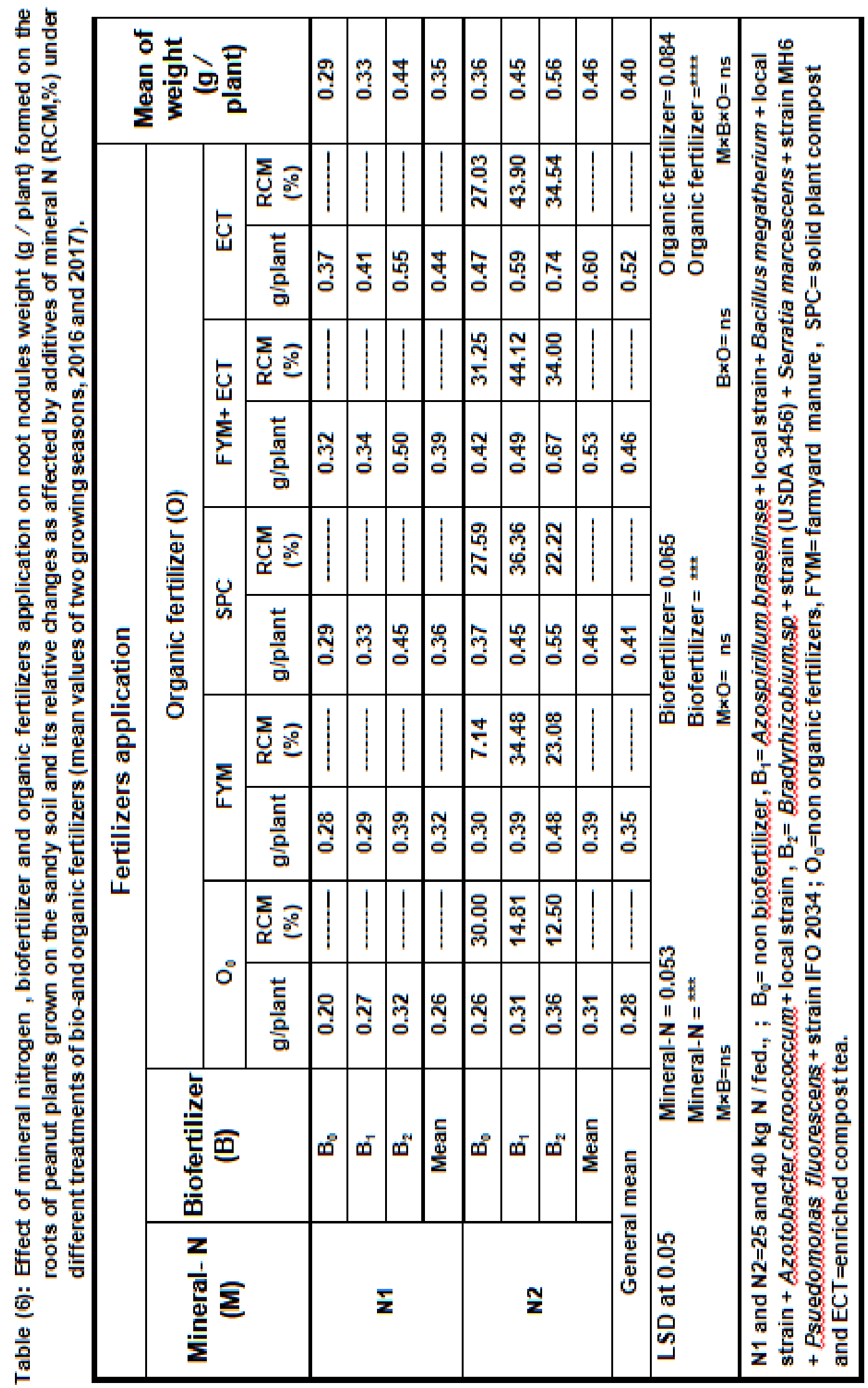


Table (7): Relative changes of root nodules weight formed on the roots of peanut plants grown on the sandy soil as affected by bio-fertilizer applications (RCB, \%) under different treatments of mineral and organic fertilizers (mean values of two growing seasons, 2016 and 2017).

\begin{tabular}{|c|c|c|c|c|c|c|}
\hline \multicolumn{7}{|c|}{ Fertilizers application } \\
\hline \multirow{2}{*}{$\begin{array}{l}\text { Mineral- N } \\
\text { (M) }\end{array}$} & \multirow{2}{*}{$\begin{array}{l}\text { Biofertilizer } \\
\text { (B) }\end{array}$} & \multicolumn{5}{|c|}{ Organic fertilizer $(0)$} \\
\hline & & $\mathrm{O}_{0}$ & FYM & SPC & FYM+ ECT & ECT \\
\hline \multirow{3}{*}{ N1 } & $\mathrm{B}_{0}$ & -- & -- & -- & - & -- \\
\hline & $B_{1}$ & 35.00 & 3.57 & 13.97 & 6.25 & 10.81 \\
\hline & $\mathbf{B}_{2}$ & 60.00 & 39.28 & 55.17 & 56.25 & 48.65 \\
\hline \multirow{3}{*}{ N2 } & $\mathbf{B}_{0}$ & - & - & - & - & - \\
\hline & $B_{1}$ & 19.23 & 30.00 & 21.62 & 17.46 & 25.53 \\
\hline & $\mathrm{B}_{2}$ & 38.46 & 60.00 & 48.65 & 59.52 & 57.45 \\
\hline \multicolumn{7}{|c|}{$\begin{array}{l}\mathrm{N} 1 \text { and } \mathrm{N} 2=25 \text { and } 40 \mathrm{~kg} \mathrm{~N} / \text { fed., ; } \mathrm{B}_{0}=\text { non biofertilizer, } \mathrm{B}_{1}=\text { Azospirillum braselinse }+ \text { local } \\
\text { strain }+ \text { Bacillus megatherium + local strain }+ \text { Azotobacter chroococcum }+ \text { local strain , } \mathrm{B}_{2}= \\
\text { Bradyrhizobium.sp + strain (USDA } 3456)+ \text { Serratia marcescens }+ \text { strain } \mathrm{MH} 6+\text { Psuedomonas } \\
\text { fluorescens }+ \text { strain IFO } 2034 ; \mathrm{O}_{0}=\text { non organic fertilizers, } \mathrm{FYM}=\text { farmyard manure , SPC= solid } \\
\text { plant compost and ECT=enriched compost tea. }\end{array}$} \\
\hline
\end{tabular}

Table (8): Relative changes of root nodules weight formed on the roots of peanut plants grown on the sandy soil as affected by organic fertilizer applications (RCO, \%) under different treatments of mineral and biofertilizers (mean values of two growing seasons, 2016 and 2017).

\begin{tabular}{|c|c|c|c|c|c|}
\hline \multicolumn{6}{|c|}{ Fertilizers application } \\
\hline \multirow{2}{*}{$\begin{array}{c}\text { Mineral- N } \\
\text { (M) }\end{array}$} & \multirow{2}{*}{$\begin{array}{l}\text { Biofertilizer } \\
\text { (B) }\end{array}$} & \multicolumn{4}{|c|}{ Organic fertilizer $(0)$} \\
\hline & & FYM & SPC & FYM+ ECT & ECT \\
\hline \multirow{3}{*}{ N1 } & $\mathrm{B}_{0}$ & 40.00 & 45.00 & 60.00 & 85.00 \\
\hline & $B_{1}$ & 7.40 & 22.22 & 25.92 & 51.85 \\
\hline & $\mathbf{B}_{2}$ & 21.87 & 40.62 & 56.23 & 71.87 \\
\hline \multirow{3}{*}{ N2 } & $\mathrm{B}_{0}$ & 15.87 & 42.31 & 61.54 & 80.77 \\
\hline & $\mathrm{B}_{1}$ & 25.81 & 45.16 & 58.06 & 90.32 \\
\hline & $\mathrm{B}_{2}$ & 33.33 & 52.77 & 86.11 & 105.55 \\
\hline \multicolumn{6}{|c|}{$\begin{array}{l}\mathrm{N} 1 \text { and } \mathrm{N} 2=25 \text { and } 40 \mathrm{~kg} \mathrm{~N} / \text { fed., ; } \mathrm{B}_{0}=\text { non biofertilizer , } \mathrm{B}_{1}=\text { Azospirillum braselinse + loca } \\
\text { strain }+ \text { Bacillus megatherium + local strain + Azotobacter chroococcum + local strain , } \mathrm{B}_{2}= \\
\text { Bradyrhizobium.sp + strain (USDA 3456) + Serratia marcescens + strain MH }+ \text { Psuedomonas } \\
\text { fluorescens + strain IFO } 2034 ; \mathrm{O}_{0}=\text { non organic fertilizers, FYM= farmyard manure , SPC= solic } \\
\text { plant compost and ECT=enriched compost tea. }\end{array}$} \\
\hline
\end{tabular}


$\mathrm{N} 1+\mathrm{B}_{0}+\mathrm{O}_{0}$ to $0.26 \mathrm{~g} / \mathrm{plants} / \mathrm{m}$ with the treatment of $\mathrm{N} 2+\mathrm{B}_{0}+\mathrm{O}_{0}$, consequently $\mathrm{RCM}$ of $30.00 \%$ occurred in the nodules weights of root plants grown in the sandy soil (Table, 6). These increases are in harmony with the nodules number formed as a result of these treatments. These increases were duo to enhanced effect of mineral $\mathbf{N}$ fertilizer on plant growth as well as its enhanced effect on microbial and enzymes activities as reported by Gad (2006) and Bekele et al. (2019) who obtained similar results with pea and groundnut plants .

Similar increases nodules weight $(\mathrm{g} / \mathrm{plants} / \mathrm{m})$ were found as a result of biofertilizations, where these increases were significant compared with those attained duo to the treatment free from biofertilization (Table, 6 and 7). At the same treatment of mineral $\mathbf{N}$ and organic fertilizers, biofertilization by $B_{2}$ resulted in higher nodules weights formed on the roots of peanut plants compared with those found on the plants biofertilized by $B_{1}$. For example, values of nodules weight resulted duo to the treatment $\mathrm{N} 1+\mathrm{B}_{1}+\mathrm{O}_{0}$ was $0.27 \mathrm{~g} / \mathrm{plants} / \mathrm{m}$ increased to $0.32 \mathrm{~g} / \mathrm{plants} / \mathrm{m}$ duo to the treatment $\mathrm{N} 1+\mathrm{B}_{2}+\mathrm{O}_{0}$. The effects of biofertilizer types on microbial and enzyme activities as well as nitrogen fixation were reported by El-Noamany (2013) and El-Zemrany et al. (2019). In this respect, the obtained results are in agreement with those reported by Tantawy et al. (2019) .

Data in Tables (6 and 7) showed high and significant increases in nodules weights ( $\mathrm{g} /$ plants $/ \mathrm{m})$ duo to the combined applications of mineral- $\mathrm{N}$ and biofertilization i.e. $\mathrm{B}_{1}$ and $B_{2}$ as compared with those found duo to their individual applications. These findings may be supported and cleared from the high values of RCM and RCB. For example, the nodules weight resulted duo to the treatment $\mathrm{N} 2+\mathrm{B}_{0}+\mathrm{O}_{0}$ was $0.26 \mathrm{~g} / \mathrm{plant}$ increased to 0.31 and $0.36 \mathrm{~g} / \mathrm{plants} / \mathrm{m}$ duo to the treatment $\mathrm{N} 2+\mathrm{B}_{1}+\mathrm{O}_{0}$ and $\mathrm{N} 2+\mathrm{B}_{2}+\mathrm{O}_{0}$, respectively corresponding to RCB values of 19.23 and $38.46 \%$. These findings mean that, the efficiency of the combined applications of mineral- $\mathrm{N}$ and biofertilizers were higher than those resulted duo to their individual applications. In contrast, Dikand et al. (2012) showed that nodulation and nitrogen fixation in $\mathrm{N}$-fertilized soybean were lower as compared to the corresponding ones resulted duo to bradyrhizobium inoculations. Nitrogen fertilization at a rate of $50 \mathrm{mg} \mathrm{N} \mathrm{kg}^{-1}$ soil was deleterious to soybean, while combined application of $10 \mathrm{mg} \mathrm{N} \mathrm{kg}^{-1}$ soil as $\mathrm{N}$ starter with any bradyrhizobium strain inoculation improved significantly nodulation.

Individual as well as combined applications of the tested $\mathbf{N}$, and biofertilizers with organic fertilizers, i.e., FYM (farmyard manure), SPC (solid plant compost), FYM (farmyard manure) + ECT (enriched compost tea) and ECT resulted in significant increases in nodules weight $(\mathrm{g} / \mathrm{plants} / \mathrm{m})$. The increases were higher with duo to the combined applications of these organic fertilizers with mineral-N or / and bio ( $B_{1}$ and $\left.B_{2}\right)$ fertilizers as compared with the individual applications (Table, 6). So, all RCO (\%) were positive (Table, 8). Also, the rate of these increases varied widely from an organic fertilizer to another depending on its chemical composition, nutrients content and $\mathrm{C} / \mathrm{N}$ ratio, (Hammad, 2019). According to the general means of nodules weight (g/plants $/ \mathrm{m}$ ) formed on the roots of peanut plants grown in sandy soil, the used organic fertilizers took the order: ECT $(0.52)>$ FYM + ECT (0.46) > SPC (0.41) > FYM( 0.35). This trend may be cleared from RCO value (\%) recorded in Table (8), where the highest RCO values of nodules weight were found with the plants fertilized by ECT followed by these found in the plants grown on the soil treated with FYM+ECT. These results are in agreement with those obtained by Abedel-Wahab et al. (2006) who found that application of compost to 
sandy soil has led to increase in plant growth of peanut crop and the nodulation status after 45 and 75 days. Recently, Hammad (2019) pointed out that with different applications rates of vinase and molase the nodules weight formed on the roots of common bean plants significantly increased as compared to the control treatment.

More significant increases in nodules weight formed on the roots of peanut plants grown in the sandy soil were found duo to dual applications of organic fertilizers with mineral and/ or $\mathbf{N}$ bio $\left(B_{1}\right.$ and $\left.B_{2}\right)$ fertilizers. The combined applications of mineral $N$ and organic fertilizers with biofertilizers showed greater increase in nodules weight as compared with these resulted duo to the combined applications of organic fertilizers and mineral-N (Table, 6). It is also shown more increase in nodules weights in the plants treated with the three types of fertilizers together, where these treatments gave the highest values of RCM, RCB and RCO (Tables, 6, 7 and 8). So, the highest values of nodules weights were associated with the treatment $\mathrm{N} 2+\mathrm{B}_{2}+\mathrm{ECT}$ followed by the treatment $\mathrm{N} 2+\mathrm{B}_{2}+\mathrm{FYM}-\mathrm{ECT}$, while the lowest one were found in the plants treated with $\mathrm{N} 1+\mathrm{B}_{0}+\mathrm{O}_{0}$. Sulfab et al. (2011) they showed that either organic manure alone or with Rhizobium inoculation plus $20 \mathrm{~kg} \mathrm{~N} \mathrm{ha}{ }^{-1}$ has significantly increased groundnuts nodulation.

\section{3- Dry matter of plant shoots plants:}

Value of dry matter of shoots ( $\mathrm{g} / \mathrm{plants} / \mathrm{m})$ of peanut plants grown on the sandy soil after 45 days of planting and its relative changes (\%) in relation with the studied individual and combined applications of mineral N (N1 and N2), bio ["B ${ }_{1}$ " Azospirillum braselinse (local strain), Bacillus megatherium, (local strain) and Azotobacter chroococcum (local strain) and " $\mathrm{B}_{2}$ " Bradyrhizobium.sp (strain (USDA 3456)), Serratia marcescens (strain MH6) and Psuedomonas fluorescens(strain IFO 2034) and organic fertilizers \{FYM (farmyard manure), SPC(solid plant compost), FYM (farmyard manure) + ECT (enriched compost tea) and ECT (enriched compost tea) \} are presented in Tables (9, 10 and 11). Increasing application rate of mineral $\mathrm{N}$ from $25 \mathrm{~kg} / \mathrm{fed}$ (N1) to $40 \mathrm{~kg} / \mathrm{fed}$ (N2) whereas individually or in combinations with bio- and / or organic fertilizers resulted in significant increases in the dry weights of peanut shoots. Therefore, all RCM values were positive. For example, shoots dry weights increased from $8.39 \mathrm{~g} / \mathrm{plants} / \mathrm{m}$ duo to the treatment $\mathrm{N} 1+\mathrm{B}_{0}+\mathrm{O}_{0}$ to $25.56 \mathrm{~g} / \mathrm{plants} / \mathrm{m}$ duo to the treatment $\mathrm{N} 2+\mathrm{B}_{0}+\mathrm{O}_{0}$, with $\mathrm{RCM}$ value of $204.65 \%$. Gogoi et al. (2000) compared the response of groundnut to different levels of $\mathrm{N}$ viz., $0,20,40,60$ and $80 \mathrm{~kg} \mathrm{ha}^{-1}$ and found that increased level of nitrogen application up to $80 \mathrm{~kg} \mathrm{ha}^{-1}$ has increased the number of branches and pegs. Munda et al. (2004) observed increase in number of branches per plant (10.1) and number of pods per plant (12.3) in groundnut as compared to the control (9.9 and 9.2) when 20:60:40 kg N, $\mathrm{P}_{2} \mathrm{O}_{5}, \mathrm{~K}_{2} \mathrm{O} \mathrm{ha}^{-1}$ were applied. Also, Ali and Seyyed (2010) reported that use of $60 \mathrm{~kg} \mathrm{ha}^{-1}$ nitrogen fertilizer resulted in the highest pod yield and kernel yield of $2314 \mathrm{~kg} \mathrm{ha}^{-1}$ and $1378 \mathrm{~kg} \mathrm{ha}^{-1}$, respectively. Ali and Ebrahim (2011) stated that nitrogen fertilizerat a rate of $\left(60 \mathrm{~kg} \mathrm{ha}^{-1}\right)$ had significant effects on kernel yield,100 kernel weight, the number of seeds plant ${ }^{-1}$, width and length of seed. Also, the maximum kernel yield of $1796 \mathrm{~kg} \mathrm{ha}^{-1}$ 
E.A. Abou Hussien, et al.,

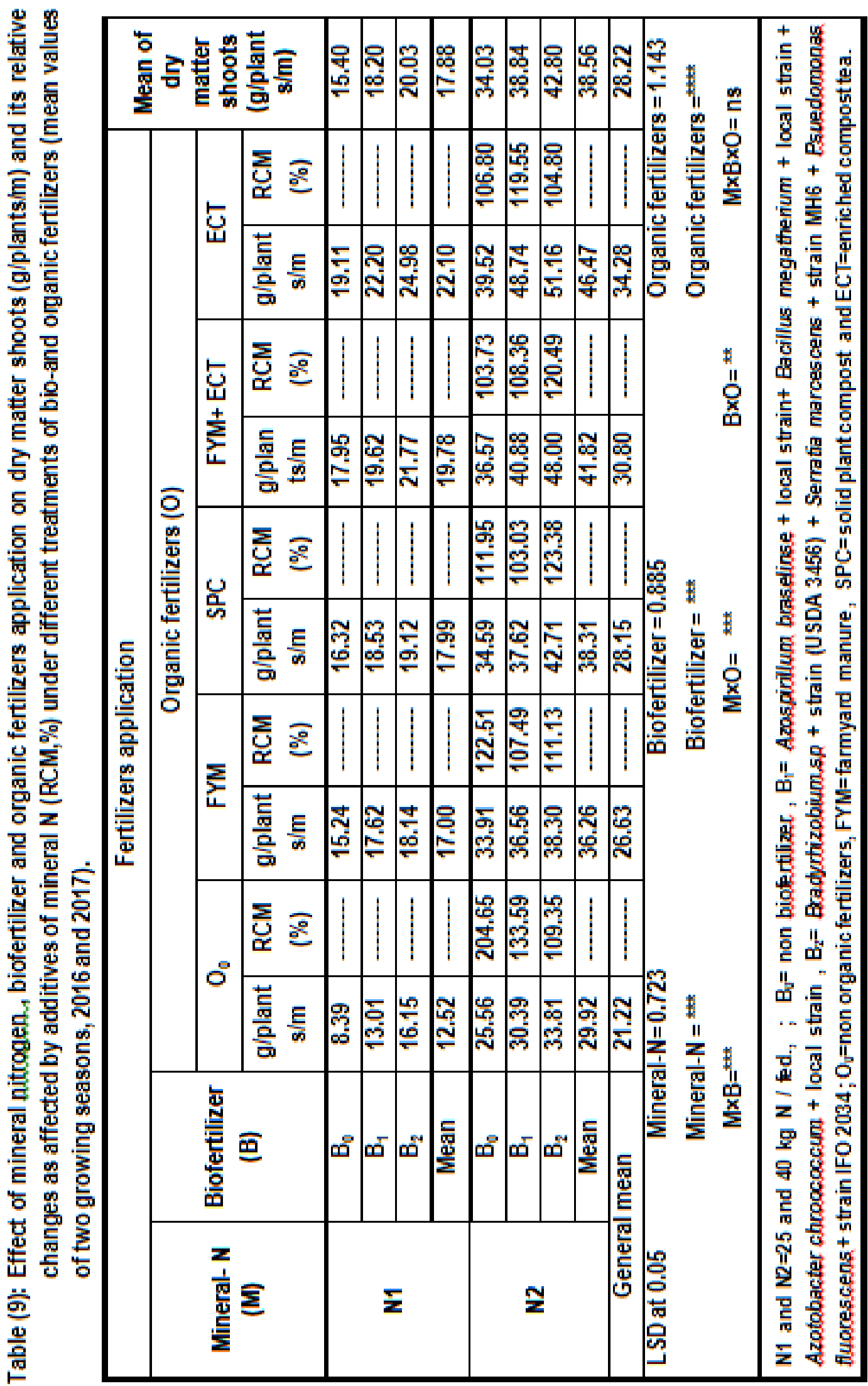


Table (10): Relative changes of dry matter shoots of peanut plants grown on the sandy soil as affected by bio-fertilizer applications (RCB, \%) under different treatments of mineral and organic fertilizers (mean values of two growing seasons, 2016 and 2017).

\begin{tabular}{|c|c|c|c|c|c|c|}
\hline \multicolumn{7}{|c|}{ Fertilizers application } \\
\hline \multirow{2}{*}{$\begin{array}{l}\text { Mineral- N } \\
\text { (M) }\end{array}$} & \multirow{2}{*}{$\begin{array}{c}\text { Biofertilizer } \\
\text { (B) }\end{array}$} & \multicolumn{5}{|c|}{ Organic fertilizer $(0)$} \\
\hline & & $\mathrm{O}_{0}$ & FYM & SPC & $F Y M+E C T$ & ECT \\
\hline \multirow{3}{*}{ N1 } & $\mathrm{B}_{0}$ & -- & -- & -- & -- & -- \\
\hline & $B_{1}$ & 55.06 & 15.62 & 13.54 & 9.30 & 16.17 \\
\hline & $B_{2}$ & 92.49 & 19.03 & 17.16 & 21.28 & 30.72 \\
\hline \multirow{3}{*}{ N2 } & $\mathrm{B}_{0}$ & - & - & - & - & - \\
\hline & $B_{1}$ & 18.90 & 7.81 & 8.76 & 11.78 & 23.33 \\
\hline & $\mathrm{B}_{2}$ & 32.28 & 12.95 & 23.47 & 31.25 & 29.45 \\
\hline
\end{tabular}

$\mathrm{N} 1$ and $\mathrm{N} 2=25$ and $40 \mathrm{~kg} \mathrm{~N} /$ fed., ; $\mathrm{B}_{0}=$ non biofertilizer , $\mathrm{B}_{1}=$ Azospirillum braselinse + local strain + Bacillus megatherium + local strain + Azotobacter chroococcum + local strain , $\mathrm{B}_{2}=$ Bradyrhizobium.sp + strain (USDA 3456) + Serratia marcescens + strain MH6 + Psuedomonas fluorescens + strain IFO $2034 ; O_{0}=$ non organic fertilizers, $F Y M=$ farmyard manure , SPC= solid plant compost and ECT=enriched compost tea.

Table (11): Relative changes of dry matter shoots of peanut plants grown on the sandy soil as affected by organic fertilizer applications (RCO,\%) under different treatments of mineral and biofertilizers (mean values of two growing seasons, 2016 and 2017).

\begin{tabular}{|c|c|c|c|c|c|}
\hline \multicolumn{6}{|c|}{ Fertilizers application } \\
\hline \multirow{2}{*}{$\begin{array}{c}\text { Mineral- N } \\
(\mathrm{M})\end{array}$} & \multirow{2}{*}{$\begin{array}{l}\text { Biofertilizer } \\
\text { (B) }\end{array}$} & \multicolumn{4}{|c|}{ Organic fertilizer $(0)$} \\
\hline & & FYM & SPC & FYM+ ECT & ECT \\
\hline \multirow{3}{*}{ N1 } & $\mathrm{B}_{0}$ & 81.64 & 94.52 & 113.94 & 127.77 \\
\hline & $\mathrm{B}_{1}$ & 35.54 & 42.54 & 50.92 & 70.77 \\
\hline & $\mathrm{B}_{2}$ & 12.32 & 18.39 & 34.80 & 54.67 \\
\hline \multirow{3}{*}{ N2 } & $\mathrm{B}_{0}$ & 32.67 & 35.33 & 43.07 & 54.62 \\
\hline & $B_{1}$ & 20.30 & 23.79 & 34.52 & 60.38 \\
\hline & $\mathbf{B}_{2}$ & 13.28 & 26.32 & 41.97 & 51.32 \\
\hline \multicolumn{6}{|c|}{$\begin{array}{l}\mathrm{N} 1 \text { and } \mathrm{N} 2=25 \text { and } 40 \mathrm{~kg} \mathrm{~N} / \text { fed., } ; \mathrm{B}_{0}=\text { non biofertilizer, } \mathrm{B}_{1}=\text { Azospirillum braselinse }+ \text { local } \\
\text { strain }+ \text { Bacillus megatherium + local strain }+ \text { Azotobacter chroococcum }+ \text { local strain }, \mathrm{B}_{2}= \\
\text { Bradyrhizobium.sp + strain (USDA } 3456)+ \text { Serratia marcescens }+ \text { strain } \mathrm{MH} 6+\text { Psuedomonas } \\
\text { fluorescens + strain IFO } 2034 ; \mathrm{O}_{0}=\text { non organic fertilizers, } \mathrm{FYM}=\text { farmyard manure, SPC= solid } \\
\text { plant compost and ECT=enriched compost tea. }\end{array}$} \\
\hline
\end{tabular}


was obtained duo to the application of nitrogen at a rate of $\left(60 \mathrm{~kg} \mathrm{ha}^{-1}\right)$. Recently, Bekele et al. (2019) has obtained similar results with groundnut plant.

Biofertilizers $\left(B_{1}\right.$ and $\left.B_{2}\right)$ in combination with mineral $\mathrm{N}$ ( $\mathrm{N} 1$ and $\mathrm{N} 2$ ) and/or organic (FYM, SPC, FYM + ECT and ECT) fertilizers caused a significant increases in shoots dry weights (g/plants $/ \mathrm{m})$ where its relative changes (RCB,\%) were recorded in Tables (9 and 10). At the same treatment of mineral $N$ and organic fertilizers, values of shoots dry weight of peanut plants biofertilized by $B_{2}$ were higher than those resulted duo to the treatment $B_{1}$. For example, value of the shoots dry weight resulted duo to the treatment $\mathrm{N} 1+\mathrm{B}_{1}+\mathrm{O}_{0}$ was 13.01 $\mathrm{g} /$ plants $/ \mathrm{m}$ and increased up to 16.15 $\mathrm{g} /$ plants $/ \mathrm{m}$ duo to the treatment $\mathrm{N} 1+\mathrm{B}_{2}+\mathrm{O}_{0}$, with $\mathrm{RCB}$ values of $55.06 \%$ and $92.49 \%$, respectively. Mohammad and Muhammad (2002) and Meghvansi et al. (2008) confirmed that co-inoculation of Rhizobium and PSB increased shoot dry weight and nitrogen and phosphorus content in shoot and phosphorus use efficiency compared to uninoculated control. Oad et al. (2002) showed that Rhizobium japonicum exhibited positive changes terms of enhanced growth and seed yield. Bai et al. (2003) found that coinoculation with Bacillus sp (strains NEB17) showed most consistent increases in shoot weight, root weight, total biomass, total nitrogen, and grain yield. B. thuringiensis NEB17 would be suitable for use as a plant growth promoting bacteria strain in soybean production systems in short growing season. Similar results were found by ElTahlawy (2018) on wheat plants grown on sandy soil ; El-Zemrany et al. (2019) on peanut plants grown in sandy soil and
Tantawy et al. (2019) on common bean plants grown on sandy and clay soils.

Organic fertilizers applications from different sources (FYM, SPC, FYM +ECT and ECT) either alone or together with mineral $N(N 1$ and $N 2)$ or/and bio(B $B_{1}$ and $B_{2}$ ) fertilizers resulted in significant increases in shoots dry weights ( $\mathrm{g} / \mathrm{plants} / \mathrm{m})$ and consequently values of $\mathrm{RCM}, \mathrm{RCB}$ and RCO (\%) as shown in Tables $(9,10$ and 11$)$. Shoots dry weight of peanut plants varied widely from on organic fertilizers to another, where at the same treatment of mineral $\mathrm{N}$ and biofertilizers. The used organic fertilizers could be warged according to their effects on increasing shoots dry weights (g/plants/m) takes the following order: FYM (26.63) < SPC (28.15) < FYM +ECT $(30.80)$ < ECT (34.28).Therefore, all RCO (\%) of shoots dry weights as affected by the applied organic fertilizers were positive as listed in Table (11). These variations reflect the improving effect of the added organic fertilizers on soil properties and its fertility as well as thier enhanced effect on microbial and enzymes activity (Abdel Aal, 2018 and Hessin, 2019).

Different combined applications of mineral $N$ (N1 and N2), bio ( $B_{1}$ and $\left.B_{2}\right)$ and organic ( FYM, SPC, FYM + ECT and ECT) in dual or in triple applications resulted in high significant increases in shoots dry weight as compared with their individual treatments as shown in Table (9). Therefore, the treatments are characterized by high values of RCM, RCB and RCO (\%) as listed in Tables $(9,10$ and 11). These findings show the higher efficiency of the studied fertilizers when added together. The highest value of shoots dry weight were recorded duo to the treatment $\mathrm{N} 2+\mathrm{B}_{2}+\mathrm{ECT}$ followed by that resulted duo to the treatment $\mathrm{N} 2+\mathrm{B}_{2}+\mathrm{FYM}-\mathrm{ECT}$ which gave shoots dry weights of 51.16 and $48.00 \mathrm{~g} / \mathrm{plants} / \mathrm{m}$, 
respectively. Sulfab et al. (2011) showed that nitrogen application at the rate of $\mathbf{2 0}$ kg N ha ${ }^{-1}$ via inoculation with rhizobia coupled with either manures resulted in significant increments in shoot and root dry weights as compared to the control. These treatments also influenced groundnuts shoot $\mathbf{N}$ and $\mathbf{P}$ accumulation and resulted in a significantly highest pod and straw yields over all other treatments under irrigated and rain fed conditions. Rizk et al. (2012) has found a response of peanut to inoculation with Bradyrhizobium either individually or in combination with PGPR (Pseudomonas fluorescens) under different levels of organic compost. Recently, El-Tahlawy (2018) and Ghaly et al. (2018) obtained similar results with wheat and common bean plants, respectively.

\section{REFERENCES}

Abbas, M. H., A. O. A. Ismail, M. A.H. ElGamal and H. M. Salem (2011). Integrated effect of mineral nitrogen, bio and organic fertilization on soybean productivity. Egypt. J. Biotechnol., 39 (October): 1-14.

Abdel Aal, M. H., D. M. Khalifa and I. M. Abdalla (2018). Impacts of different rates of compost, proline-spray and irrigation on some soil properties and sudan grass grown in saline soil. Menoufia J. Soil Sci., 3 (December): 267- 281.

Abdel-Wahab, A. F. M., F. Sh. F. Badawi, G. A. A. Mekhemar and W. M. ElFarghal (2007). Effect of enriched compost tea and Rhizobacteria on Nodulation, growth and yield of chick pea in sandy soil. Menoufia J. Agric. Res., 32 (1): 297-321.

Abdel-Wahab, A. F., G. A. A. Mekhmer, H. Shehata and A. A. Hanafi (2006). Effect of plant growth bioprotecting and promoting rhizobacteria and compost on the health and productivity of peanut crop in sandy soil. Menoufia $\mathrm{J}$. Agric. Res., 31(5): 1323-1348.

Abdel-Wahab, A. F. M., G. A. A. Mekhemar, F. Sh. F. Badawi and H. Sh. Shehata (2008). Enhancement of nitrogen fixation, growth and productivity of Bradyrhizobium-lupin symbiosis via co-inoculation with rhizobacteria in different soil types. J. Agric. Sci., Mansoura Univ., 33: 469484.

Ali, A. and A. Ebrahim (2011). The effect of nitrogen fertilizer and irrigation management on Peanut (Arachis hypogaea L.) yield in the North of Iran. ICIC $21^{\text {st }}$ International Congress on Irrigation and Drainage, 407-413.

Ali, A. G. and A. N. N. Seyyed (2010). Effects of iron and nitrogen fertilizers on yield and yield components of peanut (Arachis hypogaea L.) in Astaneh Ashrafiyeh, Iran. AmericanEurasian J. Agric. \& Environ. Sci., 9 (3): 256-262.

Amarger, N. (2001). Rhizobia in the Field. Adv. in Agron. (Ed. D.L. Sparks). Acad Press, 73: 109-167.

Bai, Y., X. Zhou and D. L. Smith (2003). Enhanced soybean plant growth resulting from coinoculation of bacillus strains with bradyrhizobium japonicum. Crop Sci., 43 (5): 1774 1781.

Basak, R. K. (2006). " Fertilizers". Kalyani Publishers, Ludhiana - New Delhi Noida (U. P. ) Hyderabad Chennai - Calcutta - Cuttack .

Bekele, G., N. Dechassa, T. Tana and J. J. Sharma (2019). Effects of nitrogen, phosphorus and vermicompost fertilizers on productivity of groundnut (Arachis hypogaea L.) in Babile, Eastern Ethiopia. Agronomy Research, 17(4): 1532-1546. https://doi.org/10.15159/AR.19.181.

Chouichom, S. and M. Yamao (2011). Organic Fertilizer Use in Northeastern Thailand: an analysis of some factors affecting farmers' attitudes. In Behnassi, M., Shahid, S.A. and D’Silva, J. (eds.): Sust Agri Devnt. Springer, Berlin, pp. 185-196.

Cottenie, A., M. Verloo, L. Kikens, G. Velghe and R. Camerlynck (1982). "Analytical Problems and Methods in Chemical Plant and Soil Analysis". Hand book ( Ed. A. Cottenie). Gent, Belgium.

Dikand, B. K., S. Sven and F. Yan (2012). Assessment of different inoculants of Bradyrhizobium japonicum on 
nodulation, potential N2 fixation and yield performance of soybean (Glycine $\max$ L.). J. Animal Plant Sci., 13(1): 1704 -1713.

El-Noamany, N. E. A. (2013). Studies on diazotrophy in soils under different conditions. M. Sc. Thesis Fac. of Agric., Menoufia Univ., Egypt.

El-Tahlawy, Y. A. (2018). Effect of microbial additives and compost tea on growth and productivity of wheat plants fertilized by mineral nitrogen in sandy soil. Menoufia J. Soil Sci., 3 (December): 301-316.

El-Zemrany, H. M., G. A. A. Mekhemar and S. S. Abd-EISalam (2019). Evaluation efficiency of liquid Bradyrhizobium and Azotobacter Chroococum DSM 2286 as co-inoculation affected by salinity level of irrigation water on peanut in sandy soils of Egypt. Menoufia J. Soil Sci., 4 (October): 201217.

Fageria, N. K., V. C. Baligar and C. Jones (1997). Growth and Mineral Nutrition of Field Crops. $2^{\text {nd }}$ Ed. Marcel Dekker, Inc, New York 1001 k, pp: 494.

Gad, N. (2006). Increasing the efficiency of nitrogen fertilization through cobalt application to pea plant. Research Journal of Agriculture and Biologicsl Sciences, 2(6): 433-442.

Ghaly, F. M. A., M. A. Soliman, A. A. Moursy, M. M. Ismail and M. M. A. Elshayeb (2018). Effect of organic and mineral nitrogen sources with and without Rhizobium inoculation on growth and yield of common bean plant using ${ }^{15} \mathrm{~N}$ tracer technique. $J$. Soil Sci. and Agric. Eng., Mansoura Univ., 9 (9)" 433 - 437.

Gogoi, P. K., R. M. Choudhury, R. Dutta and N. C. Deka (2000). Effect of levels of lime and nitrogen on production of groundnut (Arachis hypogaea L.). Crop Res., 20 : 274-278.

Hamidou, F., O. Halilou and V. Vadez (2012). Assessment of groundnut under combined heat and drought stress. J. Agron. Crop Sci., 199, 1-11. https://doi.org/10.1111/j.1439037X.2012.00518.X

Hammad, M. A. B. (2019). Combined effect of organic and mineral fertilization on nodulation and yield of common beans (Phaseolus vulgaris L.) under sandy soil conditions. M. Sc. Thesis, Fac. of Agric., Menoufia University, Egypt.

Hessin, A. M. A. (2019). Effect of gamma rays on properties of leucaena leucocephala compost under field conditions. M. Sc. Thesis Fac. of Agric., Menoufia Univ., Egypt.

Htwe, A. Z., S. M. Moh, K. M. Soe, K. Moe and T. Yamakawa (2019). Effects of biofertilizer produced from Bradyrhizobium and Streptomyces griseoflavus on plant growth, nodulation, nitrogen fixation, nutrient uptake, and seed yield of mung bean, cowpea, and soybean. Agronomy J. 9 (77): 1-15. doi:10.3390/agronomy 9020077.

Kim, H. T. (1996). " Soil Sampling, Preparation and Analysis". Marcel Dekker Inc., New York.

Latif, R., M. Islam, R. Khalid, A. Subhani and M. S. Khan Iqbal (2014). Significance of groundnut inoculation and NP fertilizer application on yield, nitrogen uptake, fixation and soil $\mathbf{n}$ balance sheet under rain fed conditions. J. Biol. Med. Sci., (2): 7-14.

Mbah, G. C. and F. D. Dakora (2018). Nitrate inhibition of $\mathrm{N} 2$ fixation and its effect on micronutrient accumulation in shoots of soybean (Glycine max $L$. Merr.), Bambara groundnut (Vigna subterranea L. Vedc) and Kersting's groundnut (Macrotyloma geocarpum Harms.). Symbiosis, 75: 205-216. https://doi.org/10.1007/s13199-0170531-2.

Meghvansi, M. K., K. Prasad and D. Harwani (2008). Response of soybean cultivars toward inoculation with three arbuscular mycorrhizal fungi and Bradyrhizobium japonicum in the alluvial. European J. Soil Biology, 44 (3): 316-323.

Mohammad, K. K. and T. Muhammad (2002). Phosphorus use efficiency of soybean as effected by phosphorus application and inoculation. Pakistan J. Agron., 1 (1): 45-50.

Munda, G. C., D. P. Patel and M. Islam (2004). Effect of macro and micronutrients on growth and yield of 
groundnut. Ann. Plant Physiol., 18(1): 9-12.

Ndakidemi, P. A., F. D. Dakora, E. M. Nkonya, D. Ringo and H. Mansoor (2006). Yield and economic benefits of common bean (Phaseolus vulgaris L.) and soybean (Glycine $\max$ L. Merr.) inoculation in northern Tanzania. Aust. J. Exp. Agric., 46: 571-577.

Oad, F. C., L. Kuma and J. K. Biswas (2002). Effect of rhizobium japonicum inoculum doses (liquid culture) on the growth and seed yield of soybean crop. Asian J. Plant Sci., 4: 340-342.

Page, A. L., R. H. Miller and D. R. Keeney (1982). "Methods of Soil Analysis". Chemical and Microbiological Properties. $2^{\text {nd }}$ Ed . Madison, Wisconsin, U.S.A.

Rasul, G. and G. B. Thapa (2003). Sustainability analysis of ecological and convention agricultural system in Bangladesh. World Development, 31 (10): 1721-1740.

Rizk, T.Y., E. M. Soliman, F. E. El-Araby and H. A. M. El-Sayed (2012). Growth response of peanut (Arachis hypogaea L.) to inoculation with Bradyrhizobium conjugated with Rhizobacteria under different levels of organic fertilization on sandy soil. Egypt. J. Agron., 34 (2): 179-200.

Samuel, G. (2013). Status of soil resources in Ethiopia and priorities for sustainable management. Ethiopian Agricultural Transformation Agency. In Launch of the Global Soil Partnership in Eastern and Southern Africa, $25^{\text {th }}-27^{\text {th }}$ of March, 2013. Nairobi, Kenya.

Siam, H. S., S. A. Mahmoud, A. S. Taalab and Kh. A. Shaban (2015). Evaluation of nitrogen levels and application methods with or without compost on yield and quality of peanut under the newly reclaimed soils. International Journal of Chem. Tech. Research, 8 (12): 1-12.

Snedecor, G.W and W.G. Cochran (1980). "Statistical Methods". $7^{\text {th }}$ Ed. The lowa State Univ. Press, Ames. Iowa, USA. pp 255-269.

Sulfab, H. A., N. O. Mukhtar, M. E. Hamad and A. I. Adam (2011). Effect of bioorganic and mineral nitrogen starter dose on growth and production of groundnuts (Arachis hypogaea L.) in Malakal Area. Journal of Science and Technology, 12(2): 13-22.

Tantawy, M. F., M. N. Fiyad, F. S. ElShafei and S. A. S. Marei (2019). Combined effect of saline and magnetized water and biofertilizer on nodulation and growth of common bean plants grown in clay and sandy soils. Menoufia J. Soil Sci., 4 (December): 293-306.

Tena, W., E. Wolde-Meskel and F. Walley (2016). Symbiotic efficiency of native and exotic Rhizobium strains nodulating lentil (Lens culinaris Medik) in soils of southern Ethiopia. Agronomy, 6: 1-11.

Vessey, J. K. and T. J. Buss (2002). Bacillus cereus UW85 inoculation effects on growth nodulation and $\mathbf{N}$ accumulation in grain legumes. Controlled environment studies. Can. J. Plant Sci., 82: 282-290.

Yusron, M. and I. R. Phillips (1997). Nitrogen leaching from urea and ammonium fertilizers under uncropped and cotton cropped conditions. Indonesian J. Crop Sci., 12 (1): $23-33$. 
تأثير إضافة النيتروجين المعدنى والسماد الحيوي على كفاعة التعقد والنمو لنباتات الفول

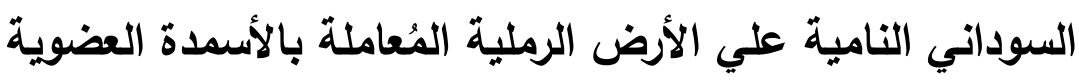

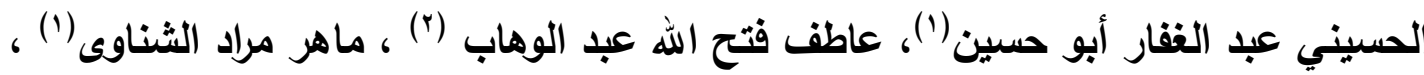

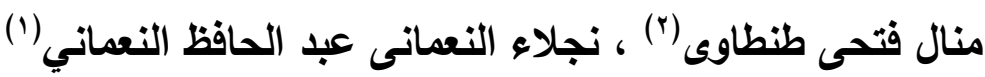

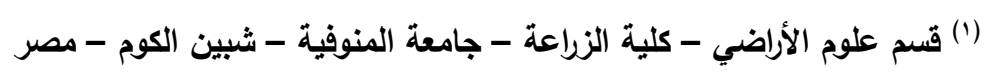

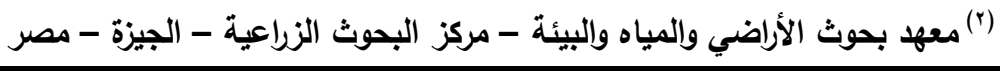

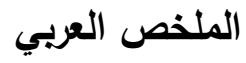

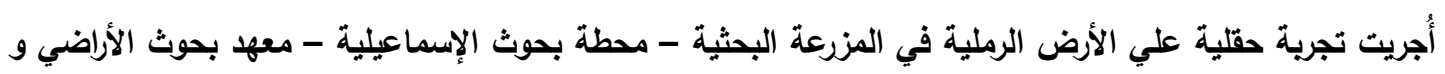

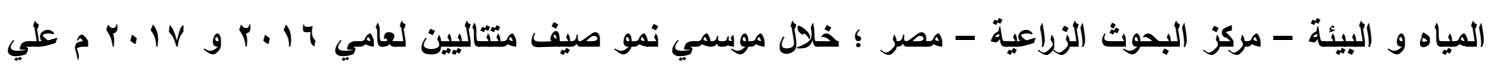

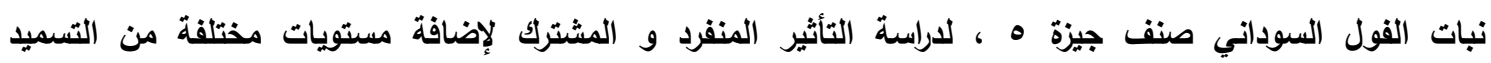

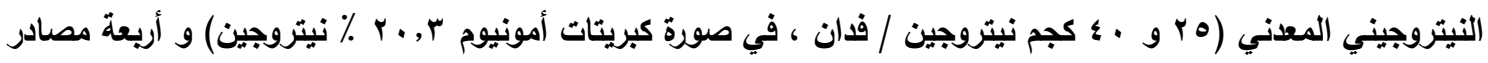

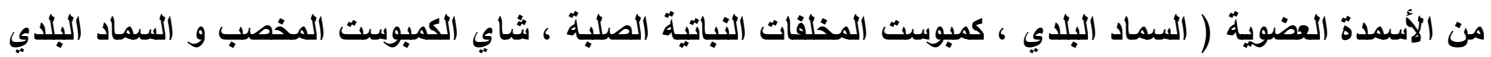

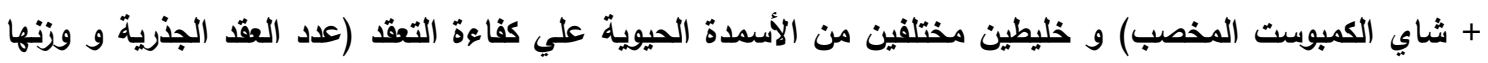

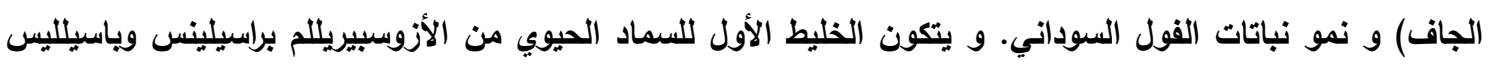

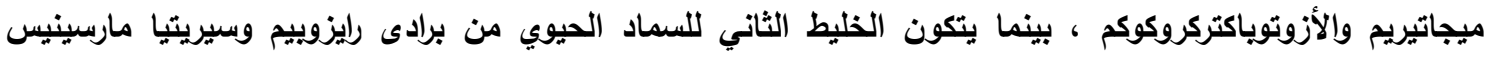

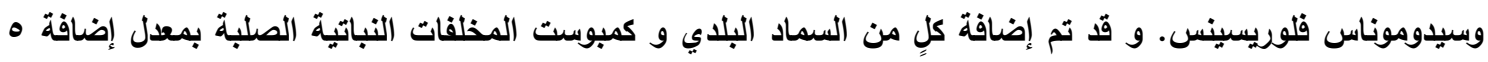

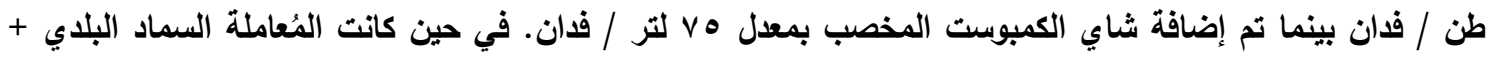

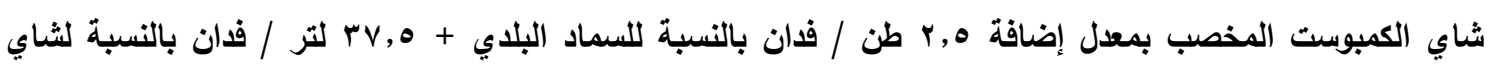

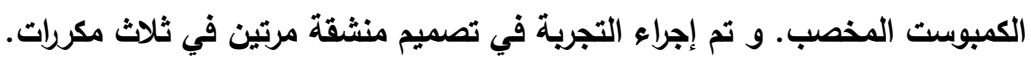

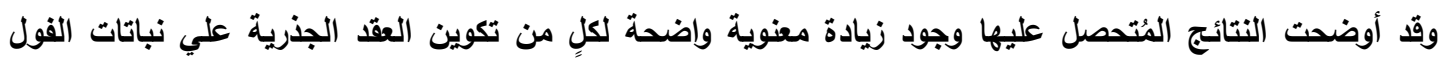

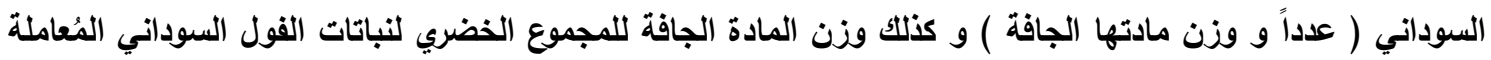

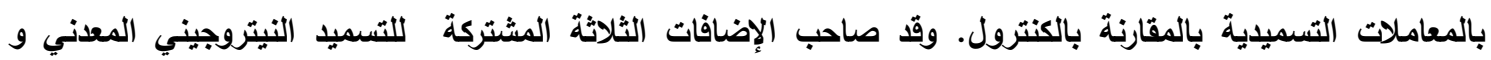

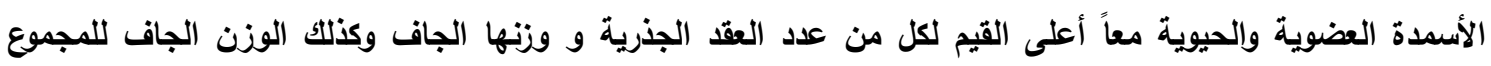

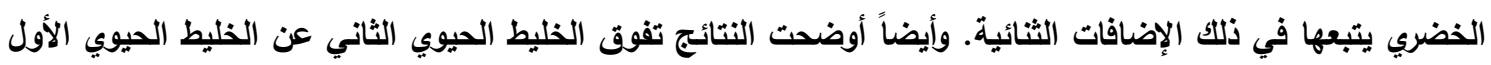

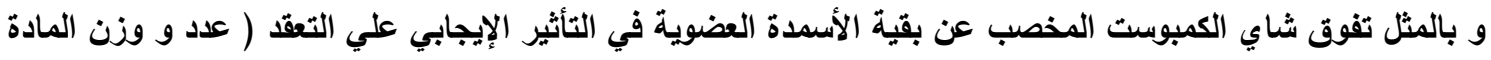

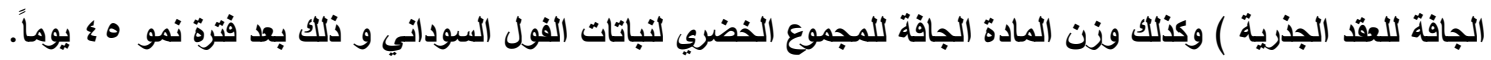

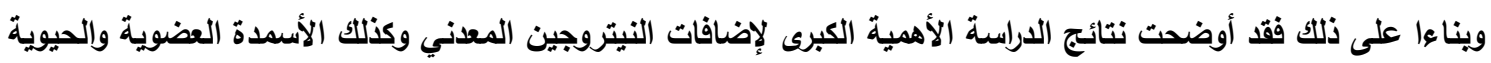

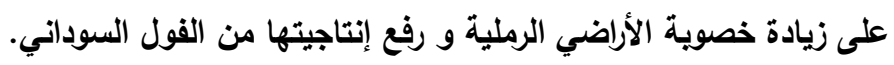

السادة المحكمين

كلية الزراعة - جامعة بنها

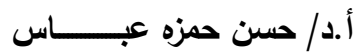

أ.د / فوزى الثاذلى أبو عجوة كلية الزراعة - جامعة المنوفية 
Effect of mineral nitrogen and biofertilizer application on nodulation ............. 